actions qui ne pouvaient manquer d'influer sur leur politique interne.

Soulignons la qualité inégale des divers rapports et extraits réunis dans ce volume et le fait que la grande majorité d'entre eux mettent l'accent davantage sur les aspects constitutionnels que sur les aspects politiques du régime. Les lecteurs qui espèrent y trouver des analyses fondées sur des modèles ou des théories récentes de la science politique resteront sur leur faim.
Malgré ses limites, cette collection de textes sera utile aux chercheurs qui s'intéressent au gouvernement de Vichy et à la Quatrième République et à tout autre lec. teur dont la curiosité est suscitée par ce gouvernement qui s'est emparé du pouvoir dans des circonstances tout à fait exceptionnelles et qui entendait l'exercer en prenant le contre-pied des pratiques antérieures.

ALAN R. Winberg Collège Algonquin

\title{
Notices
}

Avis

\section{NOMINATIONS FOR OFFICERS OF THE CPSA}

In accordance with the provisions of article viII, section 2, of the constitution of the Canadian Political Science Association, the nominating committee invites nominations for the office of President-Elect, Vice-President, Secretary-Treasurer, six Members-At-Large on the Board of Directors, and three Members of the Nominating Committee. Nominations should be in the hands of the SecretaryTreasurer (c/o University of Ottawa, Ottawa, Ontario, K1N 6N5) before 15 January 1975.

Nominations should take into consideration the geographical distribution that would include the following regions: the Atlantic provinces, Quebec, Ontario, the prairie provinces, and British Columbia.

Only nominations received before 15 January 1975 will be included in the list proposed to the membership by the nominating committee. However, names of the other candidates may be placed on the ballot by any two members submitting a nomination paper, signed by themselves and the nominee, to the secretarytreasurer before midnight of the first day of the annual meeting.

\section{NOMINATIONS DES FONCTIONNAIRES DE L'ACSP}

Selon les provisions de l'article viII, paragraphe 2, de la constitution, le comité de nomination invite les membres de l'Association canadienne de science politique à présenter des nominations au poste de président désigné, vice-président, secrétairetrésorier, et conseiller (6) du Bureau de direction, et au poste de membres (3) du comité de nomination. Les nominations doivent parvenir au secrétaire-trésorier (a/s Université d'Ottawa, Ottawa, Ontario, K1N 6N5), avant le 15 janvier, 1975.

Les nominations devraient tenir compte d'une répartition géographique qui 